\title{
ROLE OF MICRO-ENTREPRENEURSHIP IN CONSTRUCTION INDUSTRY
}

(C)Abdullayev A., Tashkent Institute of Architecture and Civil Engineering Tashkent,Uzbekistan,a.abdullayev78@mail.ru@mail.ru

\section{РОЛЬ МАЛОГО ПРЕДПРИНИМАТЕЛЬСТВА В СТРОИТЕЛЬНОЙ ПРОМЫШЛЕННОСТИ}

\section{(САбдуллаев А. Ж., Ташкентский архитектурно-строительный институт,} 2.Tашкент, Узбекистан, a.abdullayev78@mail.ru@mail.ru

Abstract. The generally accepted view of the functions of a small business as a social institution that supports the competitive environment, employment and adaptive factors of the economy: a particular lifestyle, class. A manifestation of small business opportunities in the Soviet period of development was the cooperative sector of the economy, in many of the proposed modern enterprise formats. At the same time, small business is actively developing in the investment and construction sector in a highly qualified segment in the provision of accounting services, project management, design, estimates, and most importantly, coordination of design pushes forward effectiveness of the companies.

Аннотащия. Строительная индустрия является основной частью экономики. Из-за своей динамической характеристики индустрия не будет в состоянии развиваться как сейчас. Высокий уровень конкуренции в этой отрасли подталкивает всех производителей и сектор услуг к устойчивому развитию. Новые изменения в рыночных отношениях побуждают предприятия, ведущие свою деятельность постоянно предпринимать действия для повышения своей конкурентоспособности по цене, качеству и временным факторам, введением инновационных достижений. Основной целью проводимого исследования является оценка уровня инноваций малого предпринимательства в строительной индустрии. Изначально исследования, в основном, были направлены на изучение структуры малого бизнеса в области строительства и малое предпринимательство изучалось с разной точки зрения по типу сектора. В следующей части исследования актуальность малых предприятий в строительной индустрии уточняется по уровню срочности, обобщаются результаты статических данных, даны несколько советов по развитию малого предпринимательства в области строительства.

Keywords: small business, competitiveness, construction industry, innovation, effectiveness.

Ключевые слова: малый бизнес, конкурентоспособность, строительная индустрия, инновации, эффективность.

\section{Introduction}

Among modern problems in emerging economies the construction industry is highly developed in regions. There are many opportunities for small business agents even if a high level of hazard rate. However, new construction work is still a very important issue. These studies have identified key factors that prevent the start of new construction work. These factors are divided into 
two basic categories: motivation shortcomings. The results of the research show that the ability to and financial resources. The construction industry is the main business in the world and is currently a highly profitable business. Some construction works include architect, designer, salesman, construction equipment producing and construction materials production. The built environment is usually the country's most important asset in an economic and social context. In developed countries, small business contributes $35 \%$ of people work in the construction environment and produce $30 \%$ of GDP [1].

\section{Discussion}

Construction today is a network of builders. The word 'construction' is an economistentrepreneur with an experienced construction network. One of the main factors in small business is the building of new houses all over the world. Housing is the most important factor that supports and develops civilizations and social cultures that can lead to improved housing conditions, public services, social stability, environmental conditions and participation in society (Figure 1).

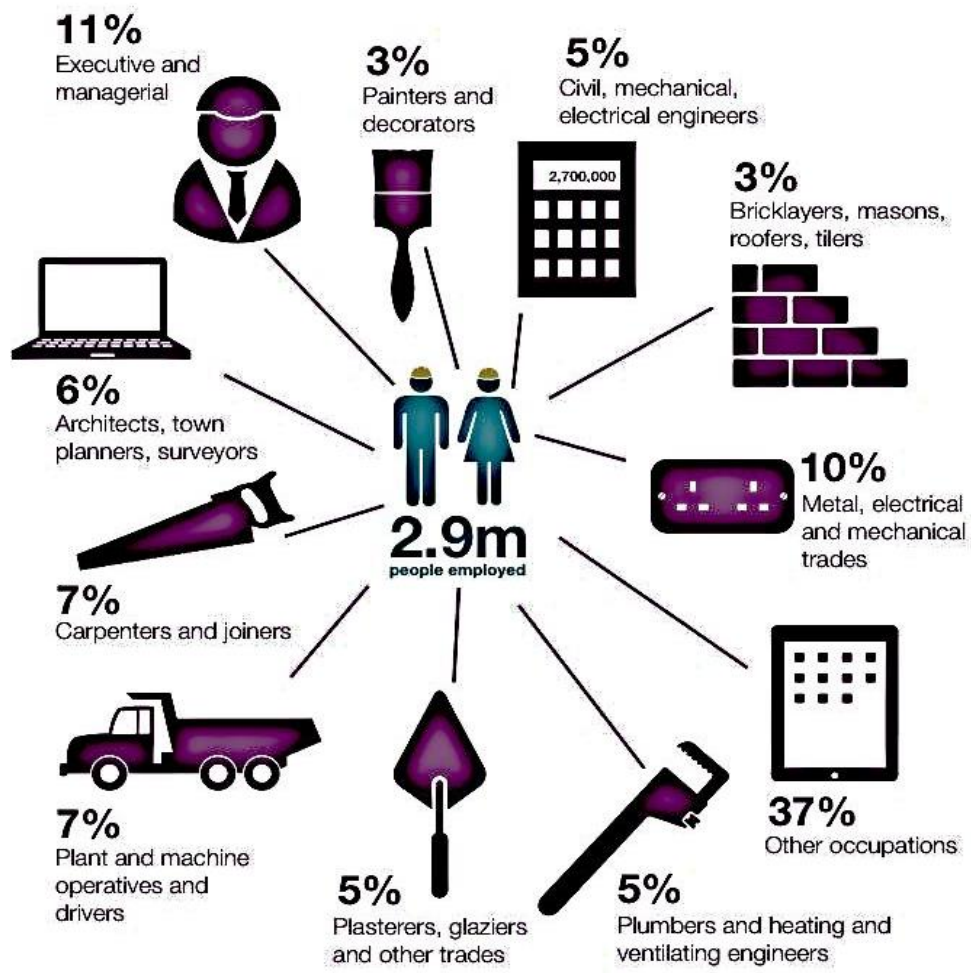

Figure 1. Structure of small business in the construction industry.

Thus, building businessmen have various opportunities to fully utilize their networks. Building objects include construction, personality and the external environment. Opportunity is a dynamic design that meets constantly changing consumer's choices [2]. In other words, personal factors and social relationships play a crucial role in determining business opportunities, especially in the construction sector. If we emphasize the lack of opportunities in the initial stages of formation, market uncertainty or the use of resources small business is a really relevant field to make money. The most important feature of a successful entrepreneur at the beginning of a start-up business is the ability to determine and select the right options. Identifying entrepreneurial opportunities is recognized as a key entrepreneurial process. The development of ideas occurs when the entrepreneur comes into contact with the environment.

During an economic downturn or depression, the housing sector is one of the sectors that will help reduce the state recession. About $9-12 \%$ of work done in the field of housing construction. In 
other words, identifying opportunities for entrepreneurship in this area can increase the level of employment and the standard of living of young people who may have a social and psychological impact on society. Given the importance of housing and its impact on other economic and social sectors, it is important to recognize existing opportunities in this area. But, above all, it is necessary to examine all aspects of identifying business opportunities in the construction sector.

Based on previous research, many aspects of entrepreneurial skills and their perception of entrepreneurship, cognitive skills, learning, creativity, financial incentives, previous knowledge/experience, social networks and entrepreneurship indices were identified. Each of the above aspects can influence the process of identifying business opportunities in the construction sector. This article discusses the four components of awareness, creativity, financial incentives, and information asymmetries for the construction industry. Main forms of small business activities indicated in the Figure 2 [3].

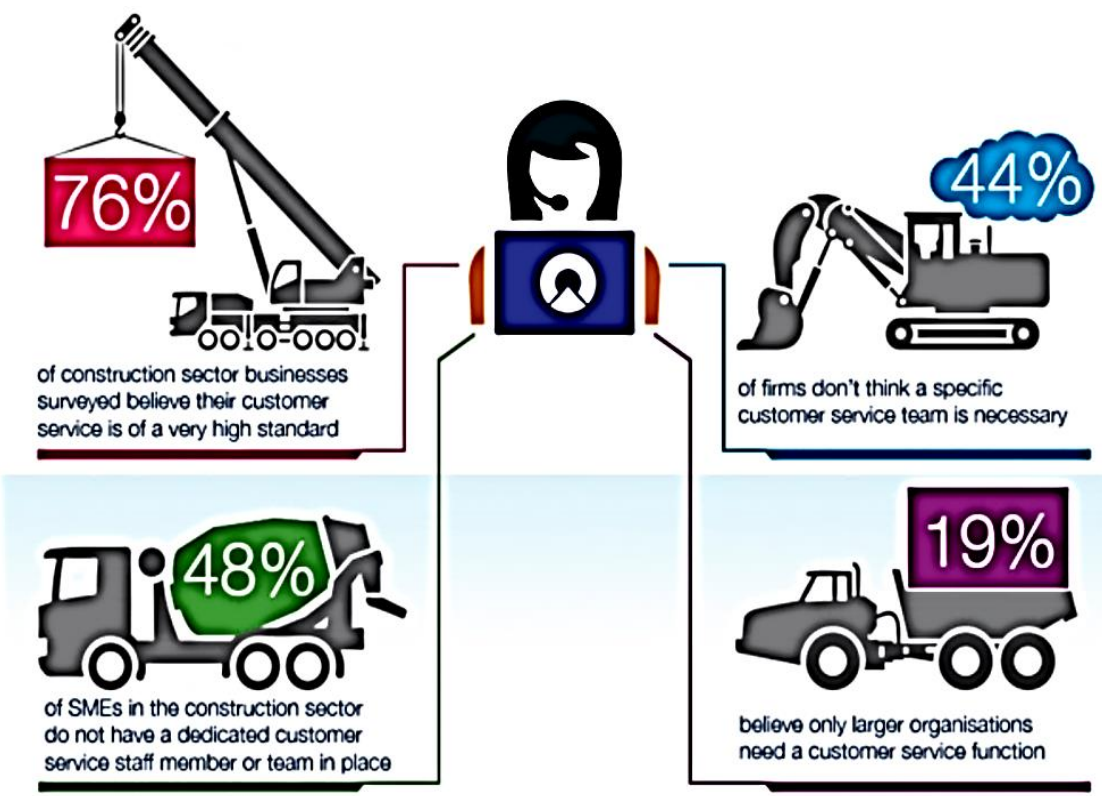

Figure 2. Small entrepreneurship type by sector.

Depending on what works, construction companies are divided into the following types:

1. Small repair contractors

Small repair contractors typically perform work requiring small capital investments and work on a large scale or large jobs that require no major construction. They usually change their homework or perform small commercial and office work. Many small repair contractors have their own offices in their homes and document at night.

\section{General contractors}

These companies are often experts in new buildings or exchanges. Many construction contractors undertake most of their work on a subcontracting basis, and repair contractors often perform most of the transactions themselves. Some general contractors are specialized in community affairs.

\section{Sector-maker}

The company, acting as a developer of the property, is not a contractor in the strict sense of the word. Such a company sells buildings only for their property or for construction or sale and use. Many builders are sometimes referred to as major contractors or construction directors as part of their core business due to their fixed capital. 


\section{Manufacturer}

This is the type of developer who can also be used to build a personal property before and after the sale. One and two family members are included in this category.

5. Professional Manager

A Professional Construction Manager may be designated as the owner of a company as a group of persons, who performs the functions required for the company, person or project, but this work is carried out with the staff of the workshop. The construction management organization usually provides all necessary personnel. Such staff includes construction managers, carriers, project managers and accounting personnel. The manager manages various parts of the construction work on behalf of the owner and pays for administrative, administrative, field supervision, requisition, contractor's payment, wage report and other work on behalf of the owner.

\section{Software Manager}

The general contractor or construction manager can extend the service by managing the program. These services include removal of existing buildings, financial analysis and development of new buildings. Buy a new site, rent a car on behalf of the architect and other designers. Providing services for the Contractor at the planning stage, providing services to the Contractor for the procurement of new jobs, consulting and financing the contractor for the procurement of new jobs, the sale of the completed project, housing or industry lease control, full project management. Obviously, the aforementioned complex services require replenishment of contractor or construction manager specialists with qualified architects, accountants, real estate professionals, management and leasing specialists.

\section{Package builders}

These companies sign contracts for the design and construction of buildings. Often these services include land acquisition and project finance. Builders are usually able to demonstrate prototypes of potential customers of buildings built for their former owners. Package builders often hire their own staff of architects and engineers as well as builders. Some packaging manufacturers transfer part of the project to independent architects or engineers. When designing a packaging design as a design and construction contract, it should be noted that most of those performing this function need to have the required professional design license or architecture [4].

Table.

SMALL ENTERPRISES IN CONSTRUCTION INDUSTRY BY LEVEL OF RELEVANCE [5]

\begin{tabular}{cc}
\hline Name of activity & Level of relevance \\
\hline Skilled Labor Shortage & Very high \\
Rising Cost of Raw Materials & High \\
Slow Invoicing and Payments & High \\
Undercapitalization & High \\
Inadequate Planning & Very high \\
Lack of Safety Training & Very high \\
Technology Adoption & Very high \\
Uncontrolled Growth & High \\
High Insurance Costs & High \\
Legacy Systems & High \\
\hline
\end{tabular}

In construction, a type of small construction enterprises is beginning to take shape; from primitive forms (repair of apartments, cottages, private houses ranging from finishing to roofing and other specialized works) to subcontracting works and even rendering services as part of the implementation of the state construction order (Table). To assess the prospects for the development 
and modification of small business formats, it is necessary to evaluate the influence of factors of the external and internal environment [6]. The external management environment includes elements of the macro-economic environment. Macromedia carries out effects that indirectly affect the economic results of any, including a small construction company. They are essentially the objective restrictions of investment and construction activities. As part of the macro environment, it is customary to single out the following factors of influence:

- general economic;

- institutional (market in nature);

- technological;

- political;

- legal.

It is requested to be very careful with construction business due to a high level of competiveness and accident rate in this area. Consumers should outstanding level of business by countries on specific approaches. In the Figure 3, it is indicated the structure of small business in construction sectors of the world major countries.

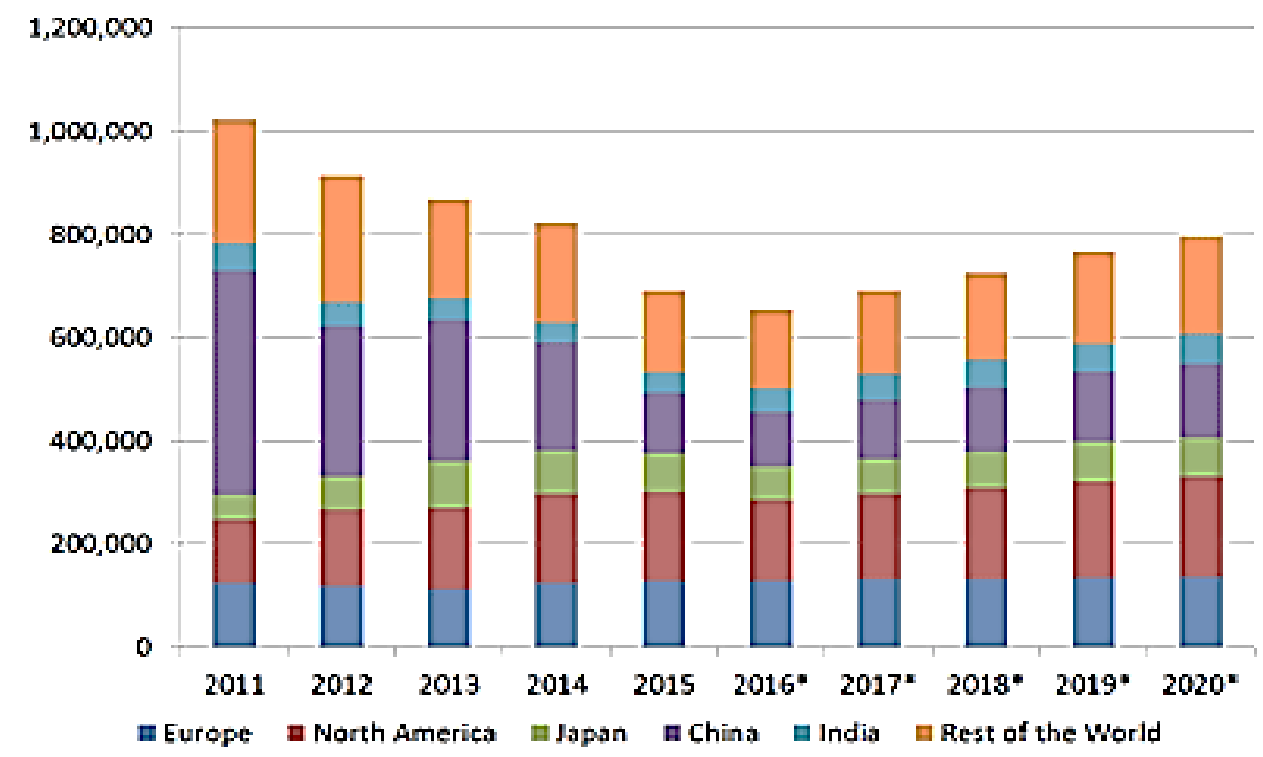

Figure 3. Role of small firms by countries in the world economy [7].

Provides small entrepreneur with the opportunity to identify develop and evaluate opportunities for higher-level business facilities. Entrepreneurs are prudent - it is a process of entrepreneurship to learn about environmental change, opportunities and chance. Awareness is described as a process and observation that helps some people to be aware of changes, shifts, opportunities, and lost opportunities. Developers are careful about business; they need to be aware of changes in the construction industry.

\section{Conclusion}

Taking into all aspects the role of small entrepreneurship in the construction industry is getting more and more flexible and adaptable. Entrepreneurial care as the beginning of a process of identifying opportunities for future thinking. Manufacturers have a full understanding about the behavior of construction in future. So we would like to offer the following professional approaches which would be reorganized or fulfilled by the business holders it will be competitive good and 
services truly will cover all building material in markets: technological backwardness; lack of functioning and adaptation skills in the market; non-professionalism during manufacturing; high production costs; low quality products; the inertia of the development of new methods of production and management, logistics; localization; innovation; export oriented; health and safety regulations.

\section{References:}

1. Voloshin, A. V. (2013). Small business in construction: development prospects. Vestnik Irkutskogo gosudarstvennogo tekhnicheskogo universiteta, (3). 129-132.

2. Khoso, A. R., Siddiqui, F. H., Khahro, S. H., \& Akhund, M. A. (2017). Entrepreneurship in Construction Industry: Motives and Barriers. International Journal of Civil Engineering and Technology, 8(6), 491-499.

3. Fletcher, D. E. (2006). Entrepreneurial processes and the social construction of opportunity. Entrepreneurship \& Regional Development, $\quad$ 18(5), 421-440. https://doi.org/10.1080/08985620600861105

4. Lu, S. L., Sexton, M. G., \& Abbot, C. (2008, November). Key characteristics of small construction firms: A United Kingdom perspective. In Proceedings: CIBW065/055 joint international symposium: transformation through construction.

5. Abesi S., Esfandabadi A. M., Esfandabadi H. M. (2016). Designing an Entrepreneurial University Model with the Organizational Entrepreneurship Approach in Payam-e-Noor University. Journal of Administrative Management, Education and Training, 12(3). 429-443.

\section{Список литературы:}

1. Волошин А. В. Малый бизнес в строительстве: перспективы развития // Вестник ИрГТУ. 2013. №3 (74). С. 129-132.

2. Khoso A. R. Siddiqui F. H., Khahro S. H., Akhund M. A. Entrepreneurship in Construction Industry: Motives and Barriers // International Journal of Civil Engineering and Techonology (IJCIET). V. 8. №6. P. 491-499.

3. Fletcher D. E. Entrepreneurial processes and the social construction of opportunity // Entrepreneurship \& Regional Development. 2006. V. 18. №5. P. 421-440.

4. Lu S. L., Sexton M. G., Abbot C. Key characteristics of small construction firms: A United Kingdom perspective // Proceedings: CIBW065/055 joint international symposium: transformation through construction. 2008.

5. Abesi S., Esfandabadi A. M., Esfandabadi H. M. Designing an Entrepreneurial University Model with the Organizational Entrepreneurship Approach in Payam-e-Noor University // Journal of Administrative Management, Education and Training. 2016. V. 12. №3. P. 429-443.

Работа поступила

в редакциию 07.03.2019 2.
Принята к публикациии 11.031.2019 2.

Cite as (APA):

Abdullayev, A. (2019). Role of Micro-Entrepreneurship in Construction Industry. Bulletin of Science and Practice, 5(4), 342-347. https://doi.org/10.33619/2414-2948/41/48.

Ссылка для циитирования:

Abdullayev A. Role of Micro-Entrepreneurship in Construction Industry // Бюллетень науки и практики. 2019. Т. 5. №4. С. 342-347. https://doi.org/10.33619/2414-2948/41/48. 